\title{
Gender Studies
}

\author{
SHIRIN M. RAI
}

In order to explore feminist perspectives on democratization we need to understand both feminist frameworks and methodologies. This chapter outlines what a feminist framework might be and then uses this perspective to analyse feminist engagements with the theory and practice of democratization.

Democratization can be defined as the process of 'making democratic' regimes, practices and discourses of public power. Luckham and White (1996b: 2-8) have identified four areas of inquiry for democratization analysts: (1) the nature of the particular institutional form of democracy; (2) causes and contexts of democratization; (3) prospects for the sustainability and deepening of democracy and (4) the relationship between democracy and socio-economic development. Rueschemeyer et al. (1992) highlighted three factors that affect the actual working of democracies: (1) the international factors - such as inter-state relations; (2) the individual state itself and its political institutions and leadership - the role of the military as opposed to civilian leadership, for example; and (3) 'civil society', which reflects the social and interest groups with a stake in society. It is, they argued, the constellation of these three factors that makes for the possibilities, or otherwise, of a successful democratization process. While valuable in themselves, both these explanatory and analytical frameworks share one fundamental characteristic - the focus is on spaces where actors, states and individuals act in the public political sphere.

The following sections present four insights arising from the work of feminist scholars that extend our understanding of democratization at the theoretical level. The analysis 
then moves to the specific field of gender and democratization and the nature of women's participation in politics. The final section reflects upon the wider socio-economic context in which men and women are engaged in democratization struggles. The conclusion holds that democratization is an untidy and unfolding process and that feminist insights are crucial for understanding it.

\section{Feminist engagements}

\section{Public and private spheres of political action}

Perhaps one of the most enduring contributions of women's activism and feminist theorizing is the challenging of the boundaries between the public and the private as defining (out) politics. In Pateman's (1983: 283) words, 'the separation of the private and public is presented in liberal theory as if it applied to all individuals in the same way'. Feminists argued that public political life was built upon the absence of women from it; that the exclusion of the private sphere was essential for the primacy of the public. By expanding the definition of politics to encompass both the public and the private spheres, indeed, by asserting that the two were mutually constitutive, feminists have been able to challenge the dominant understandings of politics itself, and therefore of democratic practice and discourse. For example, in the democratization movements against the military dictatorship installed by the coup of 11 September 1973 Chilean women called for democracy in the home as well as in politics. However, these struggles have not always been successful. While the discourse about women's position and role within the family has been carried out in the public sphere, women's presence in the public sphere has continued to be a controversial issue.

Differences remain among feminists about the nature of the public/private divide. While radical feminists have seen the obliteration of this distinction as necessary to a democracy that is inclusive of gender-based difference, others have seen such a bridging of the public and private as a transitory phase - a phase that would allow the entry of women into the public arena as independent actors (Phillips 1991 
and 1993). Some feminist scholars have argued that, while democratizing the private domain is crucial for women's participation in the public, it ought not to be confused with issues of civic participation and rights (Dietz 1992). Young, for example, has stressed the importance of maintaining the separation between the two spheres. She suggests that the private sphere should be thought of as 'that aspect of his or her life and activity that any person has the right to exclude from others. The private in this sense is not what public institutions exclude,' she argues, 'but what the individual chooses to withdraw from public view' (Young 1990: 11920). Lister (1997: 121) quite rightly points out the problems with this articulation of the public-private divide: 'it does leave open the question as to which individuals have the power to make their choices stick'. I would also emphasize, however, the need for a simultaneous, but parallel, democratization of both the public and the private spheres. Here we should insist, with Dietz, upon keeping the two domains separate. It is important to mark a conscious transition that women must make to politicize the issues that affect them within the private sphere. Rather than focusing on the issue of exclusion from the private sphere, I would emphasize the terms of inclusion into the public sphere. For it is only through making the private public that we can move forward on this issue. While not entirely answering the question of agency raised by Lister (1997), such an understanding of the bringing together of the public and the private would do so in part through the social mobilization of women (and men) on particular issues in the public sphere. Such an analysis of the public/private divide not only allows us to focus on the importance of the private for the public, but it also provides us with a measure for assessing the processes of democratization. It is both a framework of analysis and a methodology for assessing political change.

\section{Feminist methodologies}

Building upon this debate, the second insight that feminist scholars have offered is by paying particular attention to 'experience' as an important starting-point of knowledge, which contextualizes the basis of politics itself (Scott 1992). Gender, as social construction of sex, then is reflected in the political roles that women and men are able to perform, 
and 'frames the very definition of politics, and by default, what does not constitute politics' (Rai 2000: 156). From an analytical framework, which challenges the public/private divide and insists upon experience as a valid form and basis of knowledge, there emerges a radical visualization of politics itself. This visualization sees the universalized language of politics, of citizenship and rights for example, as marking the erasure of structurally embedded differences between individuals. As Blacklock and Macdonald (2000: 19) argue, women's movements are 'exposing the limitations of a discourse which, in its universalism, conceals a gendered and racialised subject identity, a Western, ethnocentric conception of rights, and an ontology which denies heterogeneity and diversity'.

The importance of context has been the third intervention that feminists have made in the debate about democratization. Feminists have pointed to the diversity of women's histories, and to their differential experiences of the public' on account of class, race, disability and sexuality, to argue for the essentially contingent and contested nature of the debate on the distinction between the public and the private spheres (Lister 1997: 122-5). They have also quite rightly asked the question: What are the costs - social, economic and personal - of political participation for women? Who has the resources to be able to participate directly? These costs are not the same, and quite often depend upon the social and economic resources that women are able to mobilize in order to access political life, to participate in informal and formal processes and political institutions. Religion, class and caste, ethnicity and sexuality, disability and language all mediate with gender to influence the outcomes of democratic participation for women and men.

\section{Patriarchy and democratic politics}

And finally, feminists have theorized on democracy with regard to the meta-framework of patriarchy. Patriarchy has been defined as a 'system of male authority which oppresses women through its social, political and economic institutions ... a sex-gender system and a system of economic discrimination operate simultaneously. Patriarchy has power from men's greater access to, and mediation of, the resources and rewards of authority structures inside and outside the 
home' (Humm 1989: 159). While there are different feminist positions on the nature of patriarchy, broadly speaking the concept does define the feminist position on social relations. So when feminists have addressed the issue of democratization, they have asked different questions and sought answers that go beyond the mainstream debates on democratization. Questions of access to and participation in the political and the socio-economic spheres, the deepening of democracy within and outside the home, are therefore, considered to be deeply gendered. The next section of this chapter builds on these discussions to assess the nature and outcomes of democratization debates and initiatives from a gendered perspective.

\section{Gender and democratization}

Waylen (1994), in her survey of the democratization literature, poses four questions about women's participation in the process of democratic transitions and consolidations: (1) Why women choose to organize or not? (2) Where they exist, what is the nature of these movements? (3) What is the interaction between women's political activities and the process of transition? and (4) What are the outcomes for women of transitions to democracy, as well as of further democratization of consolidated political systems?

\section{Women's movements and democratization}

Social movements have been defined as 'organized efforts at the grass roots to represent interests excluded from or poorly represented in formal arenas of authoritative negotiation and value allocation' (Teske and Tetreault 2000: 9). In this sense women's movements have always been part of political processes in different contexts. It is through their participation in these movements that women and women's groups have been able to stake a claim to equal representation in political life and institutions (Jayawardena 1986), on the one hand, and to focus attention on the necessity of deepening democracy within the home as they negotiate the terms upon which they participate in social and political movements in the public sphere. For example, the Hudood 
Ordinances decreed in Pakistan by its military ruler Zia ul Haq (1977-88) provoked a strong response from Pakistani women. They led to the establishment of the Women's Action Forum, which has not only mobilized against the Ordinances, which were clearly discriminatory against women, but also joined and strengthened the struggle for democracy in Pakistan (Ali 2000: 46-50). The movement of the Mothers of the Plaza de Mayo in Chile against the Pinochet regime also shows how women have challenged the separation of the public and the private by building on their role as mothers within the home to challenge authoritarian regimes in public: 'Their refusal to acquiesce in the loss of their children was not an act out of character, but a coherent expression of their socialisation [as mothers]... True to themselves, they had no other choice but to act, even it meant confronting the junta' (Navarro 1989: 257).

An important and complex area where the overlaps between the public and private spheres create challenges for women is that of 'culture'. Feminist insights have insisted upon de-mythologizing an 'essential woman' through the study of difference - between men and women and among women - as a theoretical strategy that underpins women's struggles for empowerment (Fuss 1989). However, even movements of democracy create their ideal woman erased of all differences - authenticity of culture is inscribed on women's bodies and roles. Women have sought to democratize this discourse on two counts - first, by challenging the 'orientalist' and imperialist discourse of rescue of the women of particular (non-Christian/Western) cultures (Liddle and Rai 1998); and second by challenging the codes of silence that their own communities impose on them in the name of antiracism. By challenging both these positions women have attempted to open up and deepen the democratic debate. This has not always been easy, and at times has sat uneasily with the mainstream public debate on democratization.

\section{Nature of women's political participation}

Participation in political movements has been a crucial element in the struggles for democratization. It has contributed to the creation and expansion of civil society as well as being critical to the claims of various marginalized groups for representation in national political institutions. Feminist 
scholars and activists have long been aware of the dilemmas of participation. On the one hand it is a powerful means of access and empowerment, and on the other, it places differentiated burdens and costs on participants. Issues of difference are important when discussing the nature of political participation, as is its stabilization within specific political systems. While on the whole mainstream democratization theory has been sceptical about participatory politics owing to its unpredictability and doubtful of its long-term efficacy, feminists have embraced it despite the above reservations. Lynch (1998: 162) has argued that 'theorising about social movements in the 1970s and 1980s made a double move from a critique of capitalism to an interest in the "higher goals" of rights, peace, and democracy, and from a focus on "particularistic" movements ...to movements motivated by "universalistic" values and objectives'. For the women's movements this double move created new opportunities and solidarities within the broad framework of democratization. An arena of public politics where women's movements have attempted to bring together the public and the private has expanded to include important issues of human rights $^{1}$ and citizenship. While rights, like the state, provoke different responses from feminists (see Rai 1996), human rights discourse has been central to the struggles for democracy in the 1980s and 1990s. In Guatemala, for example, the exposure of human rights violations was the first step towards building the movement for democratization. However, the movement also tried to conscientize the popular masses with 'the longer-term goal of preparing pobladoras to become citizens by organising their communities'. By raising awareness that 'all people are "entitled" to [human rights], the women's organisations are attempting to construct pobladoras as new "subjects of rights", new political actors, and new citizens' (Blacklock and Macdonald 2000: 22-3). It is through this linking of state-based rights and citizenbased conscientization that the women's movements are participating in the creation of a civil society that might be able to sustain the expansion of formal rights, as well as to challenge a universalized understanding of rights themselves.

Women's movements have also reflected the unfolding nature of citizenship. They have pressed for different facets of women's lives to be reflected in legal and constitutional 
arrangements - from the early-twentieth-century demands in many countries for universal political rights, to the current insistence upon mainstreaming a gendered perspective in political institutions. Thus, while feminists and women's movements have been wary of institutional power and discourses of universality, by opening up the issue of difference they have sought an intersection of the two. The interest in the 'third generation' of group-based human rights is evidence of this (Kymlicka 1995). In terms of democratization, this has led to some initiatives of securing women's participation in institutional politics through group-based quotas, with mixed and sometimes controversial outcomes (Rai 2002).

\section{Women's participation in institutional politics}

While mainstream democratic theory has concentrated largely on representative as opposed to participatory politics, it is only relatively recently that feminists have explored the possibilities of representative institutional politics. Debates about rights and participation in movements for democracy have led women's groups to the recognition that it is imperative that the gains made through participation are institutionalized through laws, constitutions, and political machineries and practices. Interventions of international organizations such as the United Nations also helped to emphasize the importance of working with state institutions in order to improve the living conditions of women.

Here we find significant variations depending upon the nature of political transitions and political systems, and political ideologies of leaderships, as well as different trajectories of change. Thus, during the period of transition to a democratic South Africa, the aim of the Women's National Coalition (WNC), which was the umbrella organization for 90 women's organizations representing about two million women, was to ensure that by participating in debates on the writing of the constitution they 'would be able to secure a consistent gendered perspective throughout this most important document' (Zulu 2000: 174).

While the South African case is a success story for a gender-sensitive transition politics, the experience of eastern Europe has raised important questions for women's movements as well as for democratization struggles. The 
democratization of eastern European states did not lead to more representative political institutions. On the contrary, there was a 'dramatic drop in levels of female political representation to 10 per cent or less in national assemblies after the first and second democratic elections in East Central Europe' (Einhorn 2000: 108). Together with the enormous economic pressures that families have had to experience and the abandonment of the earlier pattern of state-based participation in political institutions, women have largely stayed away from political institutions. Women have continued to be active in some eastern European countries at the level of informal, civil society politics, where they have channelled their input into being lobbying and advocacy groups under 'severe limitations on their ability to shift state policies grounded in a culture of exclusionary ethnonationalism' (Einhorn 2000: 109-10).

Within specific contexts, strategies for democratizing the state as well as civil society have thus been on the agenda of feminist democratic practice. However, a crucial context within which these strategies have taken shape and have been tried out is that of economic liberalization.

\section{Democratization and entitlements}

Feminist scholars have long challenged the view that there is a positive correlation between political and economic liberalization (Elson 1989). They have argued that the increased pressures arising from economic liberalization are increasing the burden that women carry in their daily lives and therefore reducing the time and space for them to be politically active. Globalization as liberalization is putting under pressure the idea of a stable social compact between citizens and the national states (Rai 2002: 157).

\section{Structural adjustment policies and citizenship entitlements}

Reductions in state spending on health are adversely affecting women's health as families make choices about spending limited resources on men or on boy children, and is also increasing the care burden of women as they look after 
elders and children in the absence of state provision. Similarly, education of girls has fallen dramatically in countries where structural adjustment policies (SAPs) have meant cuts in state education budgets. According to UNCTAD (2000), girl child enrolment in sub-Saharan Africa has plummeted with the introduction of SAPs. In terms of the development of the human capabilities of poor women and particularly of the women of the South, this falling investment is resulting in the erosion of their future abilities to contribute to the family income, as well as to participate in the wider political processes important to the development of their countries. Even the expansion of women's participation in the sphere of waged work in liberalized economies is no indicator of their empowerment. It could simply 'be the result either of progress towards the homogenization and equalization of the male and female employment roles, or be caused by persistence of differences in sex roles on the labour market, with demand for female labour protected by rigid patterns of sex segregation' (Rubery 1988: ix).

It could be argued that the dislocations in gendered regimes of power at the local levels caused by the expansion of female labour in export processing zones has led to women's acquiring a higher status within the family, and the opening up of new spaces outside the home for their political mobilization. Women have participated in trade union struggles as well in the wider anti-globalization/ liberalization movements. In November 1998, for example, '182 women from 22 countries representing 104 organizations met in Kuala Lumpur to Resist Globalization and Assert Our Rights'. They argued that 'privatisation of health care is a violation of women's basic human rights to total well-being' and asserted that Third World women have suffered most from globalization in Asia, where economic crisis has brought large-scale unemployment and displacement, deepening poverty, food insecurity due to increasing loss of biodiversity and the appropriation of land and water resources by large transnational corporations (TNCs) and the elite. They concluded: 'our governments, local elites and local businesses are the collaborators and implementers of this agenda'. ${ }^{2}$

Given the context of poverty and exclusion, such struggles are impressive. However, they also alert us to the limitations 
of the democratization discourse if we do not take into account the socio-economic context of political processes. Indeed, an attention to the question of citizenship entitlements of health, education and freedom from poverty is crucial if the democratization debate is to be inclusive of those on the margins of civil society. To facilitate women's active citizenship, Einhorn argues that what has been called 'exchange entitlement mapping' must be enhanced through the strengthening of the economic as well as the political rights of women.

\section{Democratization and globalization}

As is evident from the above discussion, while it may be focused on national states and political institutions and processes, democratization can no longer be discussed without attention to globalization. Thus, Held has asked: 'Whose consent is necessary, whose agreement is required, whose participation is justified in decisions concerning, for instance, the location of ... [a] nuclear plant? What is the relevant constituency? Local? National? Regional? International?' (1991: 143). We have seen the exponential growth of financial and trade flows, helped by a revolution in communications. The result has been arguments about the deterritorialization of politics, the retreat of the nation-state, and the convergence of economic policies, and about a reflexivity about the world that we inhabit and whose citizens we are. Thus it could be argued that globalization has led to the transformation of our daily lives. However, feminist engagements with globalization theory also point out that 'it is perhaps a particularly weak version of democracy that has been institutionalized on a global scale - liberal democracy in its most elitist, least developmental form' (Eschle 2001: 151). It has been argued elsewhere that '[a]s the global reach of social and political movements increases through technological and information networks, and as the pressures of international trade and markets begin to impinge significantly on the national economies leading to a fragmentation and repositioning of nation-states, the relationship between local struggles, social movements and the national state is being constantly reshaped' (Rai 2002: 205). Indeed, increasing attention is being paid to relations between women's group across national borders, focused 
on networks of women straddling North and South, and on the way in which cyber-technology is changing communications among and for women. Women are participating in struggles at the local/national as well as local/global levels (Parpart, Rai and Staudt 2002). Movements of citizens' boycotts of particular transnational corporations or products, ecological struggles for the protection of bio-diversity, the indigenous peoples' movements and indeed the women's movement have all had to operate across traditional national boundaries, and therefore to negotiate in the global political space. Issues of accountability, agenda-setting and interest representation, as well as institutionalization, have become globalized. Democratization is no longer confined within national boundaries, even though states continue to be the focus of convergence of liberal democratic institutional politics. The pressures to liberalize economies as well as polities continue to be seen as markers of convergence of democratic practice even while the outcomes of these pressures sharpen differences between states and among people.

\section{In conclusion}

As Luckham and White (1996b: 1) point out, the democratization 'wave' had already begun to recede by the mid-1990s as entrenched regimes either resisted the trend, or merely went through the democratic motions, or as newly democratic regimes succumbed to various forms of authoritarian reversion. Women's groups engaged in democratization struggles have been acutely aware of a need for constant vigilance in any engagement with state-dominated processes of democratization. Global economic trends also affect the processes and stability of democratization. Feminists' interventions in struggles for democratization have alerted them to viewing democratization as a context-bound process. State formations, the contours of particular civil societies, the possibilities of women's mobilizations, the entitlements that women have (or not), and institutional arrangements that give shape to particular citizenships have profound impacts upon the possibilities for women to participate in political life. As economic downturns affect different governments, 
issues about entitlements to citizenship become increasingly more important.

Political practice has also clarified the fact that democratization is not a wave that comes or goes - however much its jagged nature might be emphasized; it is an unfolding and untidy process. Successes in one area are not suggestive of a completeness of the process. Issues are, and need to be, revisited, with startlingly different results. Institutions that have been stable for decades, as well as new institutions of state power, need to be opened up for scrutiny. This is important because the dominant discourses of power have begun to engage with the struggles of marginalized groups, and need to be stabilized within old institutions that had been put together in another historical context. Gains that have been made must be cemented within new institutions and old. The unfolding nature of democratization is also evident when we examine the question of entitlements. As transitions from one set of socio-economic relations to another make clear, political and social citizenships do not necessarily go hand in hand. The tension within liberal democracy - of individual rights embedded in a socioeconomic context of unequal access to resources - continues to haunt throughout all the debates on entitlements. Newly democratizing nations and old democracies both are sites for the struggles for the democratization of politics.

Finally, we also need to emphasize the importance of comparative work so that women can view, analyse and perhaps use strategies for enhancing women's participation in politics across the boundaries of nation-states. The debates on citizenship - in the universalist discourse as well as those focused upon women's group rights - are particularly important in this regard (Young 1990; Lister 1997; Yuval-Davis 1997). The language of rights, of equality, of difference, and of entitlements have all been employed by women as they strategize in their pursuit of greater freedom. International fora provide meeting-places where women from different countries cross boundaries, create networks, confront constraints and explore democratic possibilities. Global frameworks, while necessarily limited, have also been utilized by women's movements to build bridges and create solidarities across national borders in their struggles to democratize politics. Feminist debates on democratization continue to 
contribute to such a rooted crossing of cultural, historical and political boundaries.

\section{Notes}

1 Only in 1991 did Amnesty International put the violation of women's rights on its agenda. Prior to this, feminist activity was not a recognized 'political' category except when integrated into the programme of a political party or trade union (Ashworth 1986: 11).

2 Statement of the Third Women's Conference Against APEC, 50years@igc.org. 